\title{
Quantitative analysis of interferon alpha receptor subunit 1 and suppressor of cytokine signaling 1 gene transcription in blood cells of patients with chronic hepatitis $C$
}

Virginia Sedeño-Monge ${ }^{1,2,4}$, Gerardo Santos-López ${ }^{1}$, Rosa C Rocha-Gracia², Daniel Meléndez-Mena ${ }^{3}$, Alberto Ramírez-Mata', Verónica Vallejo-Ruiz', Julio Reyes-Leyva ${ }^{1 *}$

\begin{abstract}
Background: Interferon (IFN)- $\alpha$ receptor 1 (ifnar1) and suppressor of cytokine signaling 1 (socs 1 ) transcription levels were quantified in peripheral blood mononuclear cells (PBMC) of 59 patients infected with hepatitis $\mathrm{C}$ virus (HCV) and 17 non-infected individuals. Samples were obtained from patients infected with HCV that were either untreated or treated with IFN- $\alpha 2$ plus ribavirin for 1 year and divided into responders and non-responders based on viral load reduction 6 months after treatment. Ifnar 1 and socs 1 transcription was quantified by real-time RT-PCR, and the fold difference $\left(2^{-\Delta \Delta C T}\right)$ with respect to hprt housekeeping gene was calculated.

Results: Ifnar1 transcription increased significantly in HCV-infected patients either untreated $(3.26 \pm 0.31)$, responders $(3.1 \pm 0.23)$ and non-responders $(2.18 \pm 0.23)$ with respect to non-infected individuals $(1 \pm 0.34 ; P=$ 0.005). Ifnar1 transcription increased significantly $(P=0.003)$ in patients infected with HCV genotypes 1a (4.74 \pm $0.25)$ and $1 \mathrm{~b}(2.81 \pm 0.25)$ but not in $1 \mathrm{a} 1 \mathrm{~b}(1.58 \pm 0.21)$. No association was found of Ifnar1 transcription with disease progress, initial viral load or other clinical factors. With respect to socs 1 transcription, values were similar for non-infected individuals $(1 \pm 0.28)$ and untreated patients $(0.99 \pm 0.41)$ but increased in responders $(2.81 \pm 0.17)$ and non-responder patients $(1.67 \pm 0.41)$. Difference between responder and non-responder patients was not statistically significant. Socs 1 transcription increased in patients infected with HCV genotypes 1a and $1 \mathrm{~b}(2.87 \pm 0.45$ and $2.22 \pm 0.17$, respectively) but not in $1 \mathrm{a} 1 \mathrm{~b}(1.28 \pm 0.40)$. Socs 1 transcript was absent in three patients infected with HCV genotype $1 \mathrm{~b}$. A weak correlation between ifnar1 and socs 1 transcription was found, when Spearman's correlation coefficient was calculated.
\end{abstract}

Conclusion: Our results suggest that HCV infection may up-regulate ifnar1 transcription. HCV genotypes differ in their capacity to affect ifnar1 and socs 1 transcription, as well as in the ability to evade the antiviral response.

\section{Background}

Hepatitis $\mathrm{C}$ virus $(\mathrm{HCV})$ is a public health concern worldwide and a major cause of chronic liver inflammation, cirrhosis and hepatocellular carcinoma (HCC) [1]. In Mexico, the prevalence of $\mathrm{HCV}$ is $\sim 1.4 \%$ in the open population and $35 \%$ in patients with active hepatitis [2].

\footnotetext{
* Correspondence: julio.reyes@imss.gob.mx

'Laboratorio de Biología Molecular y Virología, Centro de Investigación Biomédica de Oriente, Instituto Mexicano del Seguro Social, Km 4.5 carretera Atlixco-Metepec, CP 74360 Metepec, Puebla, México

Full list of author information is available at the end of the article
}

$\mathrm{HCV}$ is a single-stranded positive RNA virus that codes for a precursor polyprotein, which is processed into 10 active proteins: C, P7, E1, E2, NS2, NS3, NS4A, NS4B, NS5A and NS5B. Due to high genetic diversity, $\mathrm{HCV}$ is classified according to several genotypes and subtypes, which differ in geographic distribution, virulence and sensitivity to medical treatment [3]. In Mexico, the prevalence of genotype 1 ranges from 30 to $87.5 \%$, with a predominance of subtypes $1 \mathrm{~b}$ and $1 \mathrm{a}$. Genotypes 2 and 3 are less frequent and genotypes 4-6 are unusual in Mexican subjects [4,5].

\section{() Biomed Central}


Current therapy for $\mathrm{HCV}$ infection is the administration of pegylated IFN- $\alpha$ plus ribavirin for 24-48 weeks. However, almost $50 \%$ of treated patients do not respond to interferon therapy and, thus, are not able to clear the virus infection $[3,6]$. IFN- $\alpha$ activity is mediated by its high-affinity binding to IFN- $\alpha$ receptor (IFNAR) and subsequent induction of the Jak-Stat signaling pathway that activates transcription of $>100$ genes that establish an antiviral state in the cells [7].

The response to IFN- $\alpha$ therapy is influenced by HCV factors such as viral genotype, antigenic variability, viral susceptibility to IFN-induced proteins, expression of viral proteins that counteract IFN actions, etc. [8]. Indeed, $\mathrm{HCV}$ has developed several strategies to evade adaptive immune response and to block the action of effector proteins induced by IFN $[9,10]$.

Some host genetic factors also affect the response to IFN- $\alpha$ therapy. In addition, the presence of anti-IFN- $\alpha$ antibodies and soluble forms of human IFNAR in plasma have been implicated in the resistance to IFN- $\alpha$ therapy in patients with chronic HCV infection [10-13]. Absence of or low intrahepatic transcription of ifnar1 is also related to a poor response to IFN- $\alpha$ and severity of liver disease [13-15]. Consequently, high expression of ifnar1 in liver and PBMCs of patients with HCV have been associated with efficient IFN-induced antiviral response and clearance of virus infection [16].

Virus infection induces the expression of negative regulators of the IFN signaling pathway such as the suppressor of cytokine signaling 1 (socs 1 ), which associates with and inactivates Jak kinase, inhibiting the phosphorylation of both IFNAR and Stat proteins $[17,18]$ and downregulating the transcription of IFN-stimulated genes [19]. Conversely, transfection of HCV core protein in mouse liver silences socs 1 transcription leading to permanent activation of the Jak-Stat signaling pathway [20]. Transcriptional silencing of socs 1 gene has been found in the liver of patients with chronic HCV infection and HCC [21].

Based on the significance of ifnar1 and socs1 genes in activation/downregulation of IFN-mediated antiviral response, we developed real-time RT-PCR assays to quantify ifnar1 and socs 1 transcription in PBMCs of $\mathrm{HCV}$-infected patients, testing their usefulness in the analysis of patients' response to IFN- $\alpha$ therapy.

\section{Results}

Sixty-five HCV-infected patients were initially sampled. Samples of six patients were discarded because of their low leukocyte counts. The remaining patients were 35 females and 24 males with an age range of 20-69 years; 15/59 infected patients presented cirrhosis, 44 had active hepatitis, and none presented clinical data attributable to HCC.
Viral loads were monitored in all infected patients at 6 months after the end of treatment. Thirty-one infected and IFN-treated patients presented sustained viral response (responders, $\mathrm{R}$ ) and cleared the virus infection and remained negative to viral genome detection. Seventeen IFN-treated patients did not reduce their viral loads (non-responders, NR). Eleven infected patients were analyzed prior to treatment and were considered untreated $(\mathrm{U})$.

\section{Real-time RT-PCR assay validation}

A real-time RT-PCR assay was developed to quantify ifnar1 transcription based on the use of a TaqMan probe. To validate the detection method, we verified the amplification efficiencies of ifnar 1 and the housekeeping gene hprt using RNA from human HeLa cell line. The differences of threshold cycle $(\triangle \mathrm{CT})$ between ifnar1 and hprt $\left(\mathrm{CT}_{\text {ifnar } 1}-\mathrm{CT}_{\text {hprt }}\right)$ at several mRNA concentrations gave a lineal slope of 0.0167 (Figure 1), indicating that both genes have proportional expression efficiencies within the dynamic range of 1-16 ng.

For the analysis of socs1 transcription, a quantitative method of real-time RT-PCR based on the use of SYBR Green was developed. Validation was performed by comparing the amplification efficiencies for socs 1 and hprt genes in HeLa cells. Dynamic range for socs1 and hprt $\Delta \mathrm{CT}$ values was $1.6-15.5 \mathrm{ng}$, giving a lineal slope of -0.17 (Figure 2A). Thus, hprt can be also used for the relative quantification of socs 1 and permits to compare socs 1 and ifnar1 transcription. The specificity of SYBR Green assay was corroborated by the dissociation curves that only

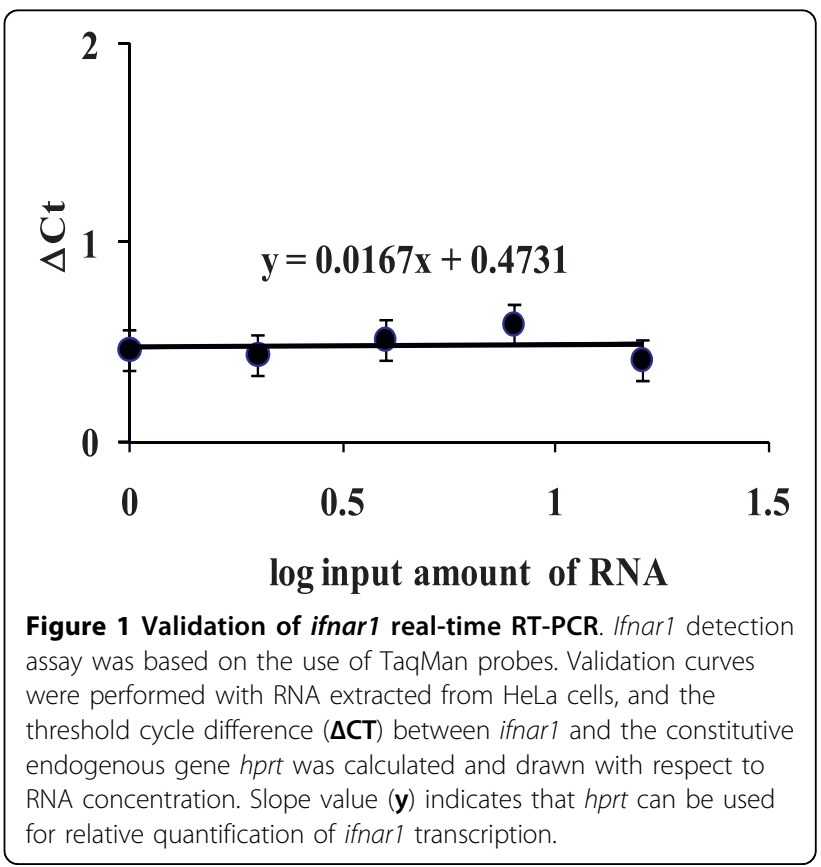



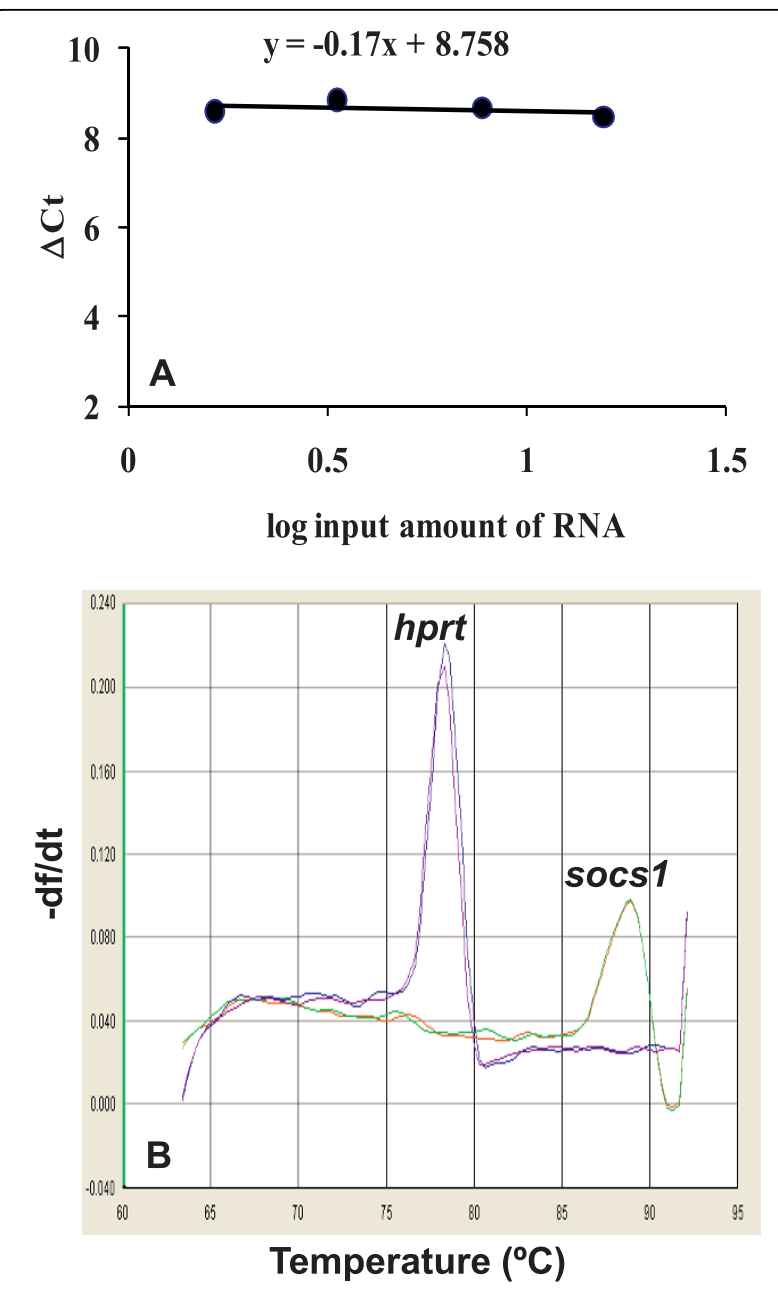

Figure 2 Validation of socs 1 real-time RT-PCR. A. Socs 1 detection assay was based on the use of Sybr Green. Validation curves were performed with RNA extracted from HeLa cells, and the threshold cycle $(\boldsymbol{\Delta C T})$ difference between socs 1 and hprt was calculated and drawn with respect to RNA concentration. Slope value $(\mathbf{y})$ indicates that hprt can be used for relative quantification of socs 1

transcription. B. Assay specificity was corroborated by means of the dissociation curves. Peaks correspond to the melting temperatures for socs 1 and hprt genes.

showed the peaks corresponding to fusion temperatures for socs 1 and hprt amplification products (Figure 2B).

\section{Ifnar1 transcription in HCV-infected patients}

For optimal relative quantification of ifnar1 mRNA the fold difference of $\Delta \mathrm{CT}\left(2^{-\Delta \Delta \mathrm{CT} \pm \mathrm{SD}}\right)$ between study groups were calculated. Resulting values were $1 \pm 0.34$ for uninfected individuals, $3.26 \pm 0.31$ for infected untreated patients, $3.1 \pm 0.23$ for infected IFN-treated responder patients and $2.18 \pm 0.23$ for non-responder patients (Figure 3A). These results indicate that ifnar 1 transcription increased significantly $(P=0.005)$ due to

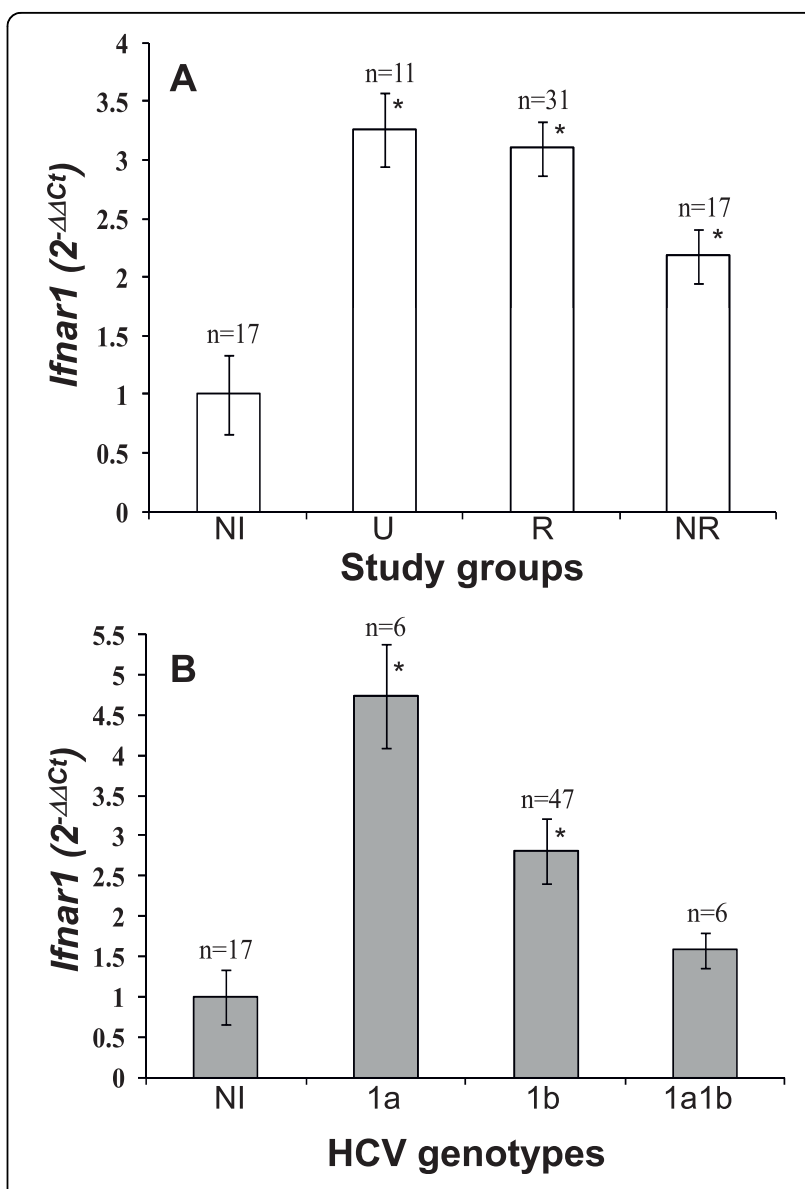

Figure 3 Ifnar 1 relative transcription. A. Relative quantification of ifnar 1 transcription was determined by real-time RT-PCR and the fold difference $\left(2^{-\Delta \Delta C t}\right)$ between study groups were calculated: noninfected controls (NI); untreated $(U)$, responders $(R)$ and nonresponder (NR) patients. B. ifnar 1 transcription in patients classified according to HCV genotype $1 \mathrm{a}, 1 \mathrm{~b}$ and $1 \mathrm{a} 1 \mathrm{~b}$ ( $\mathrm{NI}$, non-infected).

HCV infection but was not significant with respect to the patients' viral response to IFN therapy.

We analyzed if viral load, ALT level or grade of liver disease was associated with ifnar1 transcription, but no correlation was found between ifnarl transcription and any of these clinical factors (data not shown).

\section{Association of ifnar1 transcription and HCV genotypes} Infected patients were grouped according to their $\mathrm{HCV}$ genotype $1 \mathrm{a}(n=6), 1 \mathrm{~b}(n=47)$ and $1 \mathrm{a} 1 \mathrm{~b}(n=6)$. Other genotypes were not found. An association of ifnar1 transcription with viral genotype was found, thus the fold difference values for uninfected group were $1 \pm$ 0.34 , for genotype $1 \mathrm{a} 4.74 \pm 0.25$, for $1 \mathrm{~b} 2.81 \pm 0.25$, and for $1 \mathrm{a} 1 \mathrm{~b} 1.58 \pm 0.21$ (Figure 3B). Increased transcription was statistically significant for genotypes $1 \mathrm{a}$ and $1 \mathrm{~b}(P=0.003)$ but not for $1 \mathrm{a} 1 \mathrm{~b}$. 


\section{Socs 1 transcription in HCV-infected patients}

Socs 1 transcription was analyzed in 15 non-infected individuals and $50 \mathrm{HCV}$-infected patients. These corresponded to nine untreated, 29 responders and 12 non-responder patients. The calculated fold differences between study groups were $1 \pm 0.28$ for noninfected individuals, $0.99 \pm 0.41$ for untreated subjects, $2.81 \pm 0.17$ for responders and $1.67 \pm 0.41$ for nonresponders (Figure 4A). An apparent difference between responder patients and all other groups was noticed, but this was not statistically significant. No correlation was found between socs 1 transcription and ALT levels, disease progression or viral loads before treatment.

\section{Association of socs 1 transcription and HCV genotypes}

For socs 1 analysis, infected patients were grouped according to their HCV genotype $1 \mathrm{a}(n=5), 1 \mathrm{~b}(n=$

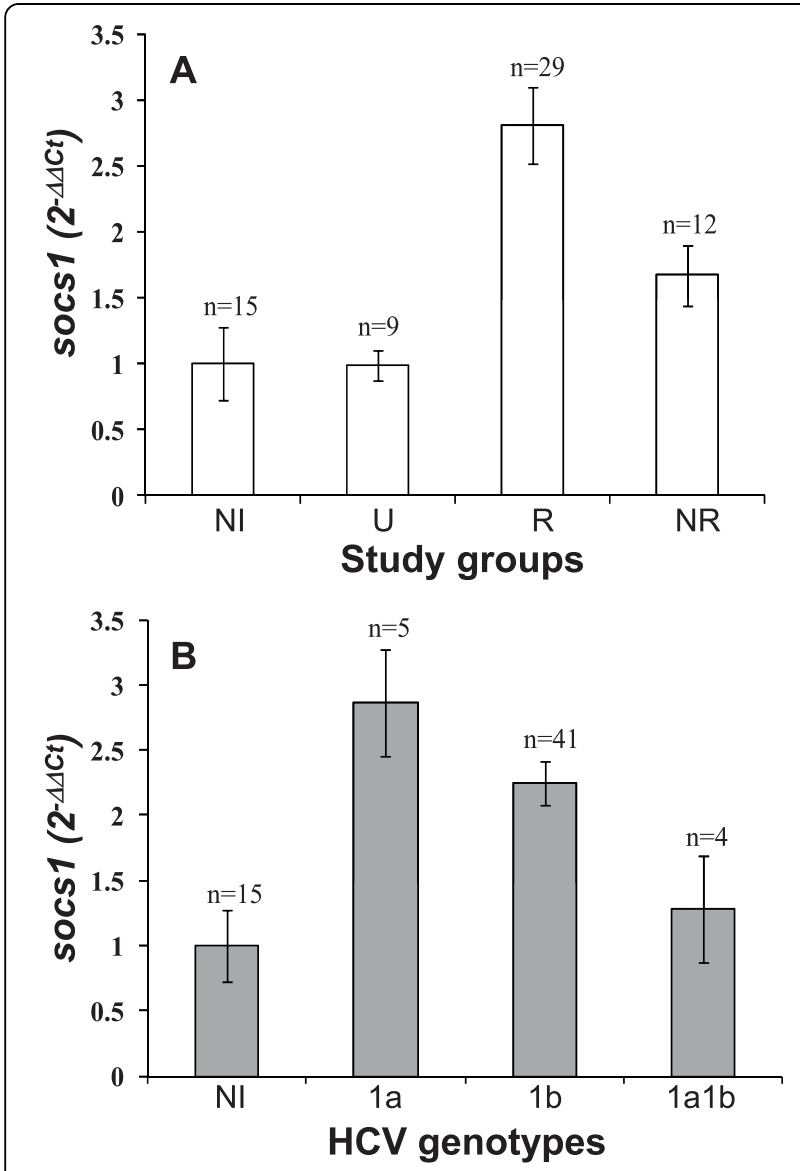

Figure 4 Socs 1 relative transcription. A. Relative quantification of socs 1 transcription was determined by real-time RT-PCR and the fold differences $\left(2^{-\Delta \Delta c t}\right)$ between study groups were calculated: noninfected controls $(\mathrm{NI})$, untreated $(\mathrm{U})$, responders $(\mathrm{R})$ and nonresponder (NR) patients. B. Socs 1 transcription in patients classified according to HCV genotype $1 \mathrm{a}, 1 \mathrm{~b}$ and $1 \mathrm{a} 1 \mathrm{~b}$ (NI, non-infected).
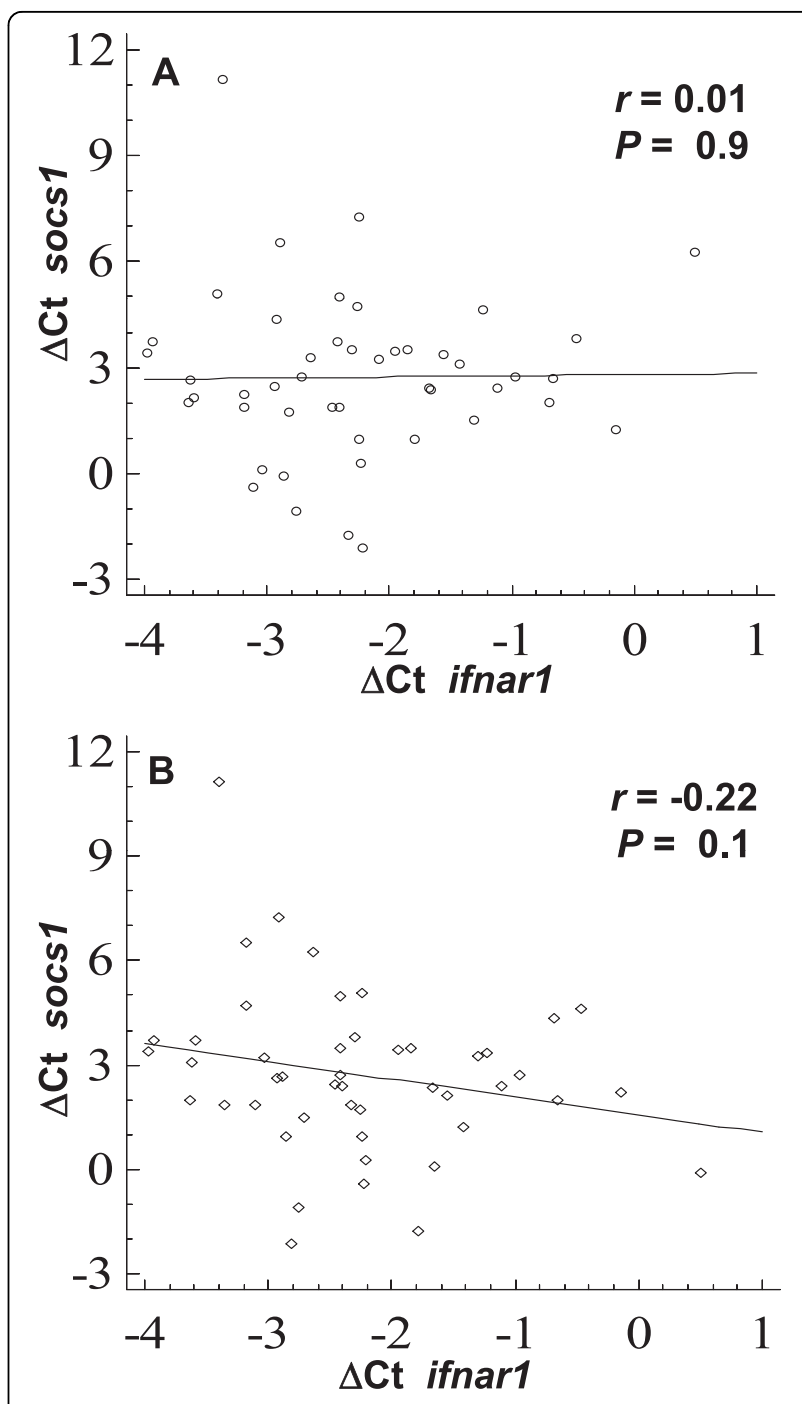

Figure 5 Correlation between ifnar 1 and socs 1 gene transcription. Spearman's correlation coefficient $(\boldsymbol{r})$ between ifnar 1 and socs $1 \triangle C T$ values was calculated. A. Analysis done with patients classified according with their response to treatment; non-infected controls (NI), untreated $(\mathrm{U})$, responders $(\mathrm{R})$ and non-responders (NR). B. Analysis done with patients grouped by HCV genotype.

41) and 1a1b $(n=4)$. Socs1 transcription increased in patients infected with HCV genotype $1 \mathrm{a}$ and $1 \mathrm{~b}(2.87 \pm$ 0.45 and $2.22 \pm 0.17$, respectively) but not in patients with genotype $1 \mathrm{a} 1 \mathrm{~b}(1.28 \pm 0.41$; Figure $4 \mathrm{~B})$. These differences were not statistically significant. Socs 1 transcripts were undetectable in $3 / 41$ patients infected with HCV genotype $1 b$.

\section{Correlation between ifnar 1 and socs 1 gene transcription}

The Spearman's correlation coefficient between ifnarl and socs 1 transcription was calculated. No correlation was found if patients were classified according with their response to treatment $(r=0.01, P=$ 0.9; Figure $5 \mathrm{~A}$ ). Instead, there was a weak inverse 
correlation between ifnar 1 and socs 1 transcription that was associated with virus genotype $(r=-0.22$, $P=0.1$; Figure $5 \mathrm{~B})$.

\section{Discussion}

We undertook this study to evaluate the association of ifnar1 and socs1 transcription with HCV infection and response to IFN therapy. We first validated the detection methods for both ifnar 1 and socs 1 transcripts and compared their amplification efficiencies with respect to the same housekeeping gene hprt. Based on their proportional expression within the dynamic range of 1 $15 \mathrm{ng}$, we concluded that hprt can be used as a reference gene for relative quantification of ifnar 1 and socs 1 transcription as well as for comparative analysis of both genes, even though we used different strategies for their detection.

Results showed increased ifnar 1 transcription in all groups of HCV-infected patients: 3.2- and 3.1-fold in the group of untreated and responder patients and only 2.1-fold in non-responder patients compared with noninfected individuals $(P=0.005)$. These results suggest that ifnar1 transcription increased due to HCV infection but was not significant for determining the association with response to treatment. We analyzed whether viral load, ALT level or grade of liver disease was associated with ifnar1 transcription, but no correlation was found between ifnar 1 transcription and any of these clinical factors.

An association of ifnar1 transcription with viral genotype was found. Indeed, ifnar 1 transcription was higher in infected patients than in non-infected individuals, 4.7-fold in patients with HCV genotype 1a, but only 2.8 and 1.6-fold in patients with genotypes $1 \mathrm{~b}$ and $1 \mathrm{a} 1 \mathrm{~b}$, respectively $(P=0.003)$. Viral genotype $1 \mathrm{~b}$ is frequently associated with advanced liver disease and lack of viral response to IFN therapy; and the latter is further associated with reduced expression of IFNAR receptors, low functionality of the Jak-Stat pathway and reduced expression of proteins with antiviral activities. This is important because $14 / 15$ patients with cirrhosis had HCV genotype $1 \mathrm{~b}$ and $8 / 17$ non responder patients had $1 \mathrm{~b}$ genotype. Controversially, patients infected with $\mathrm{HCV}$ genotypes $1 \mathrm{a} 1 \mathrm{~b}$ had the lowest ifnar 1-mRNA levels, but most of them responded to treatment. These results are not conclusive because of the scarce number of patients with genotypes $1 \mathrm{a} 1 \mathrm{~b}$ in this study.

Significant reduction of ifnar 1 mRNA and protein levels in liver has been associated with high hepatitis activity, advanced liver fibrosis, poor response to IFN- $\alpha$, and high viral load $[15,22]$. We and other authors carried out the quantification of ifnar 1 in blood cells because it is less invasive and might be correlated with virus clearance in serum, mononuclear cells and probably the liver. Previous studies have analyzed the association of ifnarl transcription in PBMCs with response to IFN therapy and reduction of serum viral loads using endpoint RT-PCR, but no correlation was found with viral clearance in liver $[16,23]$. Compared with those studies, our work improves ifnarl quantification and sensitivity because of the use of real-time RTPCR. However further experiments are required to correlate or not with the clearance of liver infection.

Experimental studies have shown that deficient production of ifnar 1 transcripts may be one of the primary defects that lead to the lack of a response to IFN- $\alpha$ in HCV-infected patients $[14,15]$. Therefore, we also analyzed socs 1 based on the hypothesis that socs 1 contributes to the lack of response by down-regulating the Jak-Stat pathway and, consequently, ifnarl transcription. At respect, socs1 gene promoter possesses transcription factor binding sites for STAT1, which both are activated by and initiate the negative feedback of the IFN-signaling pathway $[24,25]$. Our results suggested that the major inducer of socs 1 transcription was exogenous IFN- $\alpha$ treatment but not virus infection as occurred with ifnar1 transcription. The levels of socs1 transcription were similar in non-infected individuals and infected patients who were not yet under IFN treatment, whereas in patients submitted to IFN- $\alpha$ treatment the level of socs 1 transcription was higher. Although IFN therapy increased socs 1 transcription, the effect was more notable in responders than in non-responder patients (Figure 4A). This is contrary to our initial hypothesis, but it is noteworthy that analysis of socs 1 transcription can be used to pursue the response to treatment in other studies that include a higher number of patients.

We analyzed whether ifnar1 and socs1 transcription were associated, by calculating the Spearman's correlation coefficient. There was no association between ifnar 1 and socs 1 genes when patients were grouped on the basis of their response to treatment. However, these genes presented a weak inverse correlation, the lower ifnar 1 the higher socs1, when patients were classified by viral genotype.

The role of socs 1 in liver disease has been analyzed in mouse $\operatorname{socs}^{-1+}$ submitted to chemically induced fibrosis, which in addition to socs 1 reduction produces fatty degeneration of hepatic cells, macrophage infiltration and increases IL- 6 , TGF- $\beta$ and IFN- $\beta$ secretion. Those data indicate that liver reduction of socs1 increased with liver inflammation and fibrosis [26].

It is noteworthy that socs 1 transcripts were absent in 3/ 41 patients infected with genotype $1 \mathrm{~b}$. Undetectable socs 1 transcription is a frequent finding in liver biopsies of patients with HCC [21]. In addition, socs1 has been associated with tumor suppression because it reduces the 
expression of several genes involved in cell transformation [27-29] and silencing of socs1 gene leads to tumor progression [26]. In our study, none of the patients with undetectable socs 1 transcripts presented cirrhosis or HCC; however, these results suggest that silencing of socs 1 transcription started early during $\mathrm{HCV}$ infection.

\section{Conclusions}

Our results suggest that $\mathrm{HCV}$ infection may up-regulate ifnar1 transcription. Viral genotypes differ in their capacity to affect ifnar 1 and socs 1 transcription; as well as in their ability to avoid the antiviral response. Further studies should be performed to test the role of HCV genotype $1 \mathrm{~b}$ in the silencing of socs 1 transcription.

\section{Methods}

\section{Patients}

Consecutive patients with chronic HCV infection $(n=59)$ were selected from the Gastroenterology Service of the High Specialty Medical Unit, Mexican Institute of Social Security in Puebla, Mexico. Blood samples were obtained from April 2008 to August 2009. Inclusion criteria were patients of both genders, age range 20-69 years, abnormal ALT levels, positive to anti-HCV antibodies and detectable HCV RNA in serum. Patients were clinically evaluated, and laboratory tests were performed to identify stage of liver disease. Patients coinfected with HIV, HBV or other hepatitis viruses were excluded from the study; samples with scarce RNA were also excluded. Clinically healthy individuals with normal ALT values and negative tests for $\mathrm{HCV}$ infection and other viral diseases were selected for the non-infected individuals $(n=17)$.

HCV-infected patients $(n=48)$ were treated with a combination of pegylated IFN- $\alpha 2 \mathrm{a}(180 \mu \mathrm{g} /$ week $)$ and ribavirin (1000-1200 mg/day, Roche) for 48 weeks; in accordance with the hospital management rules. Eleven infected patients were analyzed prior to treatment and were considered as untreated (U) for this study. Viral loads were monitored in all infected patients with a periodicity of 6 months. Response to IFN therapy was determined on the basis of viral load reduction or virus clearance at 6 months after treatment end.

The study was carried out in accordance with ethical regulations approved by the institutional committee and in accordance with the Declaration of Helsinki.

\section{RNA extraction}

Blood samples were centrifuged at $1000 \times \mathrm{g}$ for $20 \mathrm{~min}$ and leukocyte bands were extracted and treated with red blood cell lysis buffer $(0.15 \mathrm{M}$ ammonium chloride, $10 \mathrm{mM} \mathrm{KHCO}, 0.1 \mathrm{mM} \mathrm{Na}_{2}$ EDTA) at $4^{\circ} \mathrm{C}$ for $15 \mathrm{~min}$ and centrifuged at $480 \times g$ for $4 \mathrm{~min}$. This procedure was repeated three times. Remaining white cells were washed once with phosphate-buffered saline solution.
RNA was extracted from PBMCs with Trizol reagent (Invitrogen, Carlsbad, CA, USA) following conventional procedures. RNA was air dried and treated with DNAse I (Fermentas, Glen Burnie, MD, USA). RNA concentration and quality were determined by spectrophotometry and visualized by $1 \%$ agarose gel electrophoresis with ethidium bromide.

\section{Real-time RT-PCR for ifnar 1}

All RT-PCR were set up in 96-well optical plates using 4 ng of patients' RNA, $10 \mu \mathrm{l}$ TaqMan Universal PCR Master Mix (Applied Biosystems, Foster City, CA, USA), and $1 \mu \mathrm{l}$ of primers/probe set containing $900 \mathrm{nM}$ of forward (5'-GCTTTGGATGGTTTAAGCTTTACATATAGC-3'), and reverse primers (5'-TCTGGTGAGA GTTTATAAATTTTATGTCTGGAAT-3'), and $300 \mathrm{nM}$ probe [FAM]CTTCAGGTGTAGAAGAAAG[NFQ] was added to a final volume of $20 \mu \mathrm{l}$ per reaction. Hprt was used as housekeeping gene. All samples were tested in duplicate. RT-PCR program consisted of incubation at $48^{\circ} \mathrm{C}$ for $30 \mathrm{~min}$, and 40 cycles at $95^{\circ} \mathrm{C}$ for $10 \mathrm{~min}, 95^{\circ} \mathrm{C}$ for $15 \mathrm{sec}$, and $60^{\circ} \mathrm{C}$ for $1 \mathrm{~min}$ with the 7500 Real-Time PCR System (Applied Biosystems).

$\mathrm{CT}$ and amplification efficiencies for target (ifnar1) and housekeeping (hprt) genes were tested simultaneously and compared to demonstrate their equivalence. Results were expressed in $\triangle \mathrm{CT}$, indeed target gene $\mathrm{CT}$ minus housekeeping gene CT. After this, the comparative method $2^{-\Delta \Delta C T}$ was used for relative quantification of ifnar1 transcription between study groups [30,31].

\section{Real-time RT-PCR for socs 1}

Patients' RNA samples were reverse-transcribed using the random primers included in the Two-Step RT-PCR Power SYBR Green Kit (Applied Biosystems). Reactions were done at $25^{\circ} \mathrm{C}$ for $10 \mathrm{~min}, 48^{\circ} \mathrm{C}$ for $30 \mathrm{~min}$ and $95^{\circ} \mathrm{C}$ for 5 min. socs $1 \mathrm{cDNA}$ was amplified using the Power SYBR Green Master Mix, $900 \mathrm{nM}$ of forward (5'-CACGCACTTCCGCACATTCC-3') and reverse primers (5'-TCCAGCAGCTCGAAGAGGCA-3'), and 4 ng RNA in a final volume of $20 \mu \mathrm{l}$. Then, 40 cycles were carried out at $50^{\circ} \mathrm{C}$ for $2 \mathrm{~min}, 94^{\circ} \mathrm{C}$ for $10 \mathrm{~min}, 95^{\circ} \mathrm{C}$ for $2 \mathrm{~min}, 94^{\circ} \mathrm{C}$ for $1 \mathrm{~min}, 62^{\circ} \mathrm{C}$ for $30 \mathrm{sec}$ and $72^{\circ} \mathrm{C}$ for 1 min. hprt was used as housekeeping gene. All reactions were done in duplicate. Dissociation curves were constructed at $95^{\circ} \mathrm{C}$ for $15 \mathrm{sec}, 60^{\circ} \mathrm{C}$ for $30 \mathrm{sec}, 72^{\circ} \mathrm{C}$ for 1 $\min , 45^{\circ} \mathrm{C}$ for $15 \mathrm{sec}$ and $60^{\circ} \mathrm{C}$ for $15 \mathrm{sec}$; socs 1 expression was quantified by means of the comparative method $2^{-\Delta \Delta \mathrm{CT}}$ as mentioned above.

\section{Statistical analysis}

Results expressed as $2^{-\Delta \Delta C T}$ were reported as mean \pm standard deviation and were analyzed using one-way ANOVA test. Differences between more than two 
groups were assessed by Kruskal-Wallis test. Correlations between epidemiological variables were analyzed by the Spearman test using $\Delta \mathrm{CT}$ values. $P$ values $<0.05$ were considered statistically significant.

\section{List of abbreviations}

IFNAR: interferon-alpha receptor; IFN: interferon; SOCS: suppressor of cytokine signaling; RT-PCR: reverse-transcription polymerase chain reaction; PBMC: peripheral blood mononuclear cells; HPRT: hipoxanthine guanine phosphoribosyl transferase; HCC: hepatocellular carcinoma; HCV: hepatitis C virus; ALT: alanine amino transferase; CT: threshold cycle.

\section{Competing interests}

The authors declare that they have no competing interests.

\section{Authors' contributions}

VSM, GSL, RCRG, ARM, WR and JRL participated in the study design, performing of molecular tests, data analysis, drafting and discussing of manuscript. DMM attended patients infected with hepatitis $C$ virus and assessed medical treatment and laboratory studies and participated in the analysis of clinical-epidemiological data. All authors read and approved the final manuscript.

\section{Acknowledgements}

This work was supported by Consejo Nacional de Ciencia y Tecnología México (CONACYT Salud-2003-C01-085). VSM had fellowships from Instituto Mexicano del Seguro Social and Consejo de Ciencia y Tecnología del Estado de Puebla (CONCYTEP).

\section{Author details}

'Laboratorio de Biología Molecular y Virología, Centro de Investigación Biomédica de Oriente, Instituto Mexicano del Seguro Social, Km 4.5 carretera Atlixco-Metepec, CP 74360 Metepec, Puebla, México. ${ }^{2}$ Posgrado en Microbiología, Centro de Investigaciones en Ciencias Microbiológicas, Benemérita Universidad Autónoma de Puebla, CP 72550 Puebla, Pue México. ${ }^{3}$ Servicio de Gastroenterología, UMAE, Hospital de Especialidades, Instituto Mexicano del Seguro Social, 2 norte 2004, CP 72000 Puebla, Pue., México. ${ }^{4}$ Facultad de Medicina, Universidad Popular Autónoma del Estado de Puebla, 21 sur 1103, CP 72410 Puebla, Pue., México.

Received: 23 July 2010 Accepted: 18 September 2010

Published: 18 September 2010

\section{References}

1. Anon: Global burden of disease (GBD) for hepatitis C. J Clin Pharmacol 2004, 44:20-29.

2. Valdespino JL, Conde-González JC, Olaiz FG, Palma O, Kershenobich D, Sepulveda J: Seroprevalencia de la hepatitis $C$ en adultos de México: ¿un problema de salud pública emergente? Salud Publica Mex 2007, 49. S395-S403.

3. Anon: NIH Consensus Statement on Management of Hepatitis C: 2002. NIH Consens State Sci Statements 2002, 19:1-46.

4. Santos-Lopez G, Sosa-Jurado F, Vallejo-Ruiz V, Melendez-Mena D, ReyesLeyva J: Prevalence of hepatitis $C$ virus in the Mexican population: a systematic review. I Infect 2008, 56:281-290.

5. Sosa-Jurado F, Santos-Lopez G, Guzman-Flores B, Ruiz-Conde Jl, MelendezMena D, Vargas-Maldonado MT, Martinez-Laguna Y, Contreras-Mioni L, Vallejo-Ruiz V, Reyes-Leyva J: Hepatitis C virus infection in blood donors from the state of Puebla, Mexico. Virol J 2010, 7:18.

6. Fried MW, Shiffman ML, Reddy KR, Smith C, Marinos G, Goncales FL Jr, Häussinger D, Diago M, Carosi G, Dhumeaux D, Craxi A, Lin A, Hoffman J, Yu J: Peginterferon alfa-2a plus ribavirin for chronic hepatitis $C$ virus infection. N Engl J Med 2002, 347:975-982.

7. Stark GR, Kerr IM, Williams BR, Silverman RH, Schreiber RD: How cells respond to interferons. Annu Rev Biochem 1998, 67:227-264.

8. Barnes $E$, Webster $G$, Whalley $S$, Dusheiko G: Predictors of a favorable response to alpha interferon therapy for hepatitis C. Clin Liver Dis 1999, 3:775-791.
9. Polyak SJ, Gerotto M: The molecular basis for responsiveness to anti-viral therapy in hepatitis C. Forum (Genova) 2000, 10:46-58.

10. Han JQ, Barton DJ: Activation and evasion of the antiviral $2^{\prime}-5^{\prime}$ oligoadenylate synthetase/ribonuclease $L$ pathway by hepatitis $C$ virus mRNA. RNA 2002, 8:512-525.

11. Castelruiz $Y$, Larrea $E$, Boya $P$, Civeira MP, Prieto J: Interferon alfa subtypes and levels of type I interferons in the liver and peripheral mononuclear cells in patients with chronic hepatitis C and controls. Hepatology 1999, 29:1900-1904.

12. Taylor DR, Shi ST, Lai MM: Hepatitis C virus and interferon resistance. Microbes Infect 2000, 2:1743-1756

13. Mizukoshi E, Kaneko S, Kaji K, Terasaki S, Matsushita E, Muraguchi M, Ohmoto $Y$, Kobayashi K: Serum levels of soluble interferon alfa/beta receptor as an inhibitory factor of interferon in the patients with chronic hepatitis C. Hepatology 1999, 30:1325-1331.

14. Fukuda R, Ishimura N, Ishihara S, Tokuda A, Satoh S, Sakai S, Akagi S, Watanabe $M$, Fukumoto $S$ : Expression of interferon-alpha receptor mRNA in the liver in chronic liver diseases associated with hepatitis $C$ virus: relation to effectiveness of interferon therapy. J Gastroenterol 1996, 31:806-811.

15. Ishimura N, Fukuda R, Fukumoto S: Relationship between the intrahepatic expression of interferon-alpha receptor mRNA and the histological progress of hepatitis $C$ virus-associated chronic liver diseases. Gastroenterol Hepatol 1996, 11:712-717.

16. Yamaguchi Y, Hino K, Fujiwara D, Ren F, Katoh Y, Satoh Y, Okita K Expression of type I interferon receptor in liver and peripheral blood mononuclear cells in chronic hepatitis C patients. Dig Dis Sci 2002, 47:1611-1617.

17. Frey KG, Ahmed CM, Dabelic R, Jager LD, Noon-Song EN, Haider SM, Johnson HM, Bigley NJ: HSV-1-induced SOCS-1 expression in keratinocytes: use of a SOCS-1 antagonist to block a novel mechanism of viral immune evasion. J Immunol 2009, 183:1253-1262.

18. Wormald S, Hilton DJ: Inhibitors of cytokine signal transduction. J Biol Chem 2004, 279:821-824.

19. Brand S, Zitzmann K, Dambacher J, Beigel F, Olszak T, Vlotides G, Eichhorst ST, Goke B, Diepolder H, Auernhammer CJ: SOCS-1 inhibits expression of the antiviral proteins $2^{\prime}, 5^{\prime}-\mathrm{OAS}$ and MxA induced by the novel interferon-lambdas IL-28A and IL-29. Biochem Biophys Res Commun 2005, 331:543-548

20. Miyoshi H, Fujie H, Shintani Y, Tsutsumi T, Shinzawa S, Makuuchi M, Kokudo N, Matsuura Y, Suzuki T, Miyamura T, Moriya K, Koike K: Hepatitis C virus core protein exerts an inhibitory effect on suppressor of cytokine signaling (SOCS)-1 gene expression. J Hepatol 2005, 43:757-763.

21. Yoshikawa H, Matsubara K, Qian GS, Jackson P, Groopman JD, Manning JE, Harris CC, Herman JG: SOCS-1, a negative regulator of the JAK/STAT pathway, is silenced by methylation in human hepatocellular carcinoma and shows growth-suppression activity. Nat Genet 2001, 28:29-35.

22. Fukuda R, Ishimura N, Kushiyama $Y$, Moriyama N, Ishihara S, Nagasawa S, Miyake T, Niigaki M, Satoh S, Sakai S, Acagi S, Watanabe M, Fukumoto S: Effectiveness of interferon-alpha therapy in chronic hepatitis $C$ is associated with the amount of interferon-alpha receptor mRNA in the liver. J Hepatol 1997, 26:455-461.

23. Massirer KB, Hirata MH, Silva AE, Ferraz ML, Nguyen NY, Hirata RD: Interferon-alpha receptor $1 \mathrm{mRNA}$ expression in peripheral blood mononuclear cells is associated with response to interferon-alpha therapy of patients with chronic hepatitis C. Braz J Med Biol Res 2004, 37:643-647.

24. Jegalian $A G, W u$ H: Regulation of Socs gene expression by the protooncoprotein GFI-1B: two routes for STAT5 target gene induction by erythropoietin. J Biol Chem 2002, 277:2345-2352.

25. Saito H, Morita Y, Fujimoto M, Narazaki M, Naka T, Kishimoto T: IFN regulatory factor-1-mediated transcriptional activation of mouse STATinduced STAT inhibitor-1 gene promoter by IFN- $\gamma$. I Immunol 2000, 164:5833-5843.

26. Yoshida $T$, Ogata H, Kamio M, Joo A, Shiraishi H, Tokunaga Y, Sata M, Nagai H, Yoshimura A: SOCS1 is a suppressor of liver fibrosis and hepatitis-induced carcinogenesis. J Exp Med 2004, 199:1701-1707.

27. Rottapel R, llangumaran S, Neale C, La Rose J, Ho JM, Nguyen MH, Barber D, Dubreuil $P$, de Sepulveda $P$ : The tumor suppressor activity of SOCS-1. Oncogene 2002, 21:4351-4362. 
28. Kishimoto $\mathrm{T}$, Kikutani $\mathrm{H}$ : Knocking the SOCS off a tumor suppressor. Nat Genet 2001, 28:4-5.

29. Ilangumaran $S$, Rottapel R: Regulation of cytokine receptor signaling by SOCS1. Immunol Rev 2003, 192:196-211.

30. Livak K, Schmittgen TD: Analysis of relative gene expression data using real-time quantitative PCR and the 2(-Delta Delta $C(T))$ Method. Methods 2001, 25:402-408.

31. Schmittgen TD, Livak KJ: Analyzing real-time PCR data by the comparative C(T) method. Nat Protoc 2008, 3:1101-1108.

doi:10.1186/1743-422X-7-243

Cite this article as: Sedeño-Monge et al:: Quantitative analysis of interferon alpha receptor subunit 1 and suppressor of cytokine signaling 1 gene transcription in blood cells of patients with chronic hepatitis C. Virology Journal 2010 7:243.

Submit your next manuscript to BioMed Central and take full advantage of:

- Convenient online submission

- Thorough peer review

- No space constraints or color figure charges

- Immediate publication on acceptance

- Inclusion in PubMed, CAS, Scopus and Google Scholar

- Research which is freely available for redistribution

Submit your manuscript at www.biomedcentral.com/submit
C Biomed Central 